Muchadenyika, D. \& Williams, J.J. (2018). Politics, centralisation and service delivery in urban

\title{
Politics, centralisation and service delivery in urban Zimbabwe
}

\author{
Davison Muchadenyika and John J. Williams
}

\begin{abstract}
The politics of urban control has revolved around centralisation since independence in 1980. However, such politics became more pronounced after 2000 owing to the rise of the opposition Movement for Democratic Change (MDC) as the main governing party in urban areas. Political tensions and contradictions ensued between central government, under the Zimbabwe African National Union (Patriotic Front) (ZANU[PF]), and local authorities, under the MDC, over the control and administration of urban areas. Based on 30 interviews, the article explains how central government and, by extension, ZANU(PF) attempted to regain control of urban areas through centralisation of water and vehicle licensing functions. This practice, however, contravenes existing laws. Hitherto, scholarship has attributed centralisation by the government to a strategy to defuse the opposition rule in cities. This article extends reasons for centralisation to include ZANU(PF)'s strong ideological belief in centralisation, access to resources in a failing economy and maintaining a firm grip on power. In particular, the article focuses on how urban politics is manifested in the transfer of water and sanitation and vehicle licensing functions from local authorities to government-run entities. It is also evident that the prioritisation of survival politics neglects key service delivery in urban centres. In the absence of a functionally devolved system of governance, this casts doubt on the feasibility and success of opposition political parties in governing African cities.
\end{abstract}

\section{Introduction}

In Africa, the nexus between politics and service delivery has become an important area of study, owing largely to the rise of opposition political parties in governing cities. ${ }^{1}$ Thus service delivery is often mired in and destabilised by deeply contested politics. In many African cities, urban political realities are contested and 'service delivery is used as a source and resource for political agency'. ${ }^{2}$ This is most evident in countries such as Uganda, Senegal, South Africa, Zambia and Zimbabwe, in instances where opposition parties govern major cities. Parties controlling national governments have a tendency to subdue and weaken

\footnotetext{
${ }^{1}$ D. Resnick, 'Urban Governance and Service Delivery in African Cities: The Role of Politics and Policies', Development Policy Review, 32, S1 (2014), pp. s3-s17; D. Muchadenyika, 'Land for Housing: A Political Resource - Reflections from Zimbabwe's Urban Areas', Journal of Southern African Studies, 41, 6 (2015), pp. 1219-38; D. Resnick, 'In the Shadow of the City: Africa's Urban Poor in Opposition Strongholds', Journal of Modern African Studies, 49, 1 (2011). pp. 141-66; D. Muchadenyika and J.J. Williams, 'Social Change: Urban Governance and Urbanization in Zimbabwe', Urban Forum, 27, 3 (2016), pp. 253-74.

${ }^{2}$ Muchadenyika, 'Land for Housing', p. 1220.
} 
opposition-controlled cities, as the success of such cities can propel opposition parties to national governance.

This article explores how urban politics is manifested through centralisation of functions by the national government in urban areas run predominantly by the opposition party. In particular, we explain the struggle to control urban centres in Zimbabwe between two political parties, the opposition MDC and the ruling ZANU(PF). In doing so, we examine two cases, namely the transfer of water and sanitation and vehicle licensing functions from local authorities to government-run entities. Such centralisation has, however, destroyed the institutional foundations of service delivery.

It has been argued that 'repressive forms of political interventions in city governance' explain the dysfunctionality of water and sanitation services in Harare. 3 In regions that have been critical of ZANU(PF) rule since 1980, such as Bulawayo, water has been used as a political tool to punish opposing views. 4 The politicisation of urban water and sanitation brought the national government through the 'back door' to control everyday life in cities. However, it should be noted that, in Zimbabwe, the political struggle to control water has both colonial and post-colonial antecedents. 5 In essence, it would seem that the post-colonial government resorted to political strategies of the colonial government to strip post-colonial cities of power and resources needed to flourish. Existing arguments on the centralisation of water, notably from Muchaparara Musemwa, focus on ethnic and regional tensions and political retribution, primarily in Bulawayo. ${ }^{6}$

Here, we extend centralisation arguments to include access to resources by the national government in a debilitating economic environment, ZANU(PF)'s strong ideological belief in centralisation as a tool to organise the state and its desire to maintain a firm grip on power. We explore these arguments through focusing on two local government functions namely water and sanitation, and vehicle licensing - which were centralised in 2005 and 2010 respectively. Moreover, the article argues that the victims of centralisation are not only Bulawayo (as portrayed in existing studies), but all urban centres that have been centres of democratic transition; they are all affected by the ZANU(PF)'s centralisation of governance.

Other than centralisation of urban functions, urban politics in Zimbabwe is manifested in various other ways. First, through the use of massive socio-spatial re-engineering exercises masked in the name of bringing sanity and order in cities. Yet the main motive seems to be political retribution and dilution of perceived opposition strongholds. Such exercises include the Operation Murambatsvina or Restore Order (OM/RO) presented as a campaign to eradicate illegal housing and economic activities from the cities although such justifications

\footnotetext{
${ }^{3}$ M. Musemwa, 'From "Sunshine City" to a Landscape of Disaster: The Politics of Water, Sanitation and Disease in Harare, Zimbabwe, 1980-2009', Journal of Developing Societies, 26, 2 (2010), p. 165.

${ }^{4}$ See M. Musemwa, 'Disciplining a "Dissident" City: Hydropolitics in the City of Bulawayo, Matabeleland, Zimbabwe, 1980-1994', Journal of Southern African Studies, 32, 2 (2006), pp. 239-54.

${ }^{5}$ See M. Musemwa, 'Early Struggles over Water: From Private to Public Water Utility in the City of Bulawayo, Zimbabwe, 18941924', Journal of Southern African Studies, 34, 4 (2008), pp. 881-98

${ }^{6}$ See M. Musemwa, Water, History and Politics in Zimbabwe: Bulawayo's Struggles with the Environment, 1894-2008 (Trenton, Africa World Press, 2014).
} 
obscure far deeper economic and political causes'.7 In essence, OM/RO largely shows the use of coercion by ZANU(PF) in response to urban discontent toward its rule. ${ }^{8}$ Sara Rich Dorman argues that OM/RO shows the exclusionary nature of urban politics in Zimbabwean cities in which urban citizens are seen as 'politically unreliable'. ${ }^{9}$

Second, urban politics is expressed through the use of informal and parallel structures to perform functions of local authorities. This strategy includes the use of political party structures and militia to control and parcel out urban land, and controlling and allocating flea markets to loyal ZANU(PF) supporters. ${ }^{10}$ Access to urban land and markets is therefore traded for ZANU(PF) loyalty. In an informal economy like Zimbabwe, access to urban land and markets is crucial to one's survival and livelihood. ${ }^{11}$ Hence, we suggest that the ruling party uses its power to determine who has access to such vital resources in an environment where urban unemployment is extremely high.

Third, central government exerts control through the apparently systematic suffocation of cities' access to critical resources for urban expansion, such as land. In the post-2000 era, the national government did not transfer state land to urban councils by issuing Deeds of Grant. Instead, government allocated state land directly to ZANU(PF) structures, supporters and co-operatives through the local government ministry. ${ }^{12}$ This is more pronounced in cities run by the opposition party, such as Harare, Bulawayo and Mutare, among others. In this regard, Muchadenyika argues that urban land is a vital political resource used by the ZANU(PF) to influence and control urban development and undermine the role and power of opposition-run cities. ${ }^{13}$

Fourth, urban politics is seen in the use and abuse of local government laws by the national government to disturb and undermine the power of the MDC in running cities. Largely, this includes the appointment of ZANU(PF) loyalists as special interest councillors, ${ }^{14}$ the use of the Local Government Board to appoint senior council officials, and the dismissal of MDC mayors and councillors. 15 Here ZANU(PF) uses its power to determine who runs cities. This political strategy has largely weakened the ability of MDC to govern cities, as appointed officials wield more power than councillors and mayors.

\footnotetext{
${ }^{7}$ D. Potts, “'Restoring Order”? Operation Murambatsvina and the Urban Crisis in Zimbabwe', Journal of Southern African Studies, 32, 2 (2006), p. 273.

${ }^{8}$ F. Musoni, 'Operation Murambatsvina and the Politics of Street Vendors in Zimbabwe', Journal of Southern African Studies, 36, 2 (2010), pp. 301-17,

9 S.R. Dorman, "WWe Have Not Made Anybody Homeless": Regulation and Control of Urban Life in Zimbabwe', Citizenship Studies, 20, 1 (2016), pp. 84-98.

10 J. McGregor, 'Surveillance and the City: Patronage, Power-Sharing and the Politics of Urban Control in Zimbabwe', Journal of Southern African Studies, 39, 4 (2013), pp. 783-805.

11 D. Muchadenyika, 'Social Movements and Planning Institutions in Urban Transformation: Housing in Metropolitan Harare, Zimbabwe (2000-2015)' (DPhil thesis, University of the Western Cape, 2017).

12 Ibid.

${ }^{13}$ See Muchadenyika, 'Land for Housing'.

${ }^{14}$ Special interest councillors were meant 'to cater for special needs of specific groups such as disabled, business, civil society among others' and 'provide a caveat for some groups who cannot be fully represented based on elected councillors'. See Muchadenyika and Williams, 'Social Change', p. 264.

15 D. Muchadenyika and J.J. Williams, 'Central-Local State Contestations and Urban Management in Zimbabwe', Journal of Contemporary African Studies (forthcoming).
} 
It is in these contexts that the move to centralise water provision services and vehicle licensing functions can be understood. The article is based on 30 interviews conducted with mayors and councillors, administrative heads of city departments, local government professionals (within and outside government ministries and departments, international development agencies, community-based organisations and civil society organisations) and representatives of political parties and research institutes. ${ }^{16}$

\section{The Politics of Urban Control in Zimbabwe}

The rise of opposition political parties in controlling local governments in the 2000 s and the struggle by ZANU(PF) to retain political dominance resulted in the centralisation of administrative authority and power. ${ }^{17}$ In this instance, centralisation was an attempt to allow government the opportunity to commandeer service delivery at the local level. Other than weakening local authorities, centralisation is a strategy to make the central government relevant in the daily lives of urban residents, who, in most cases, vote for the opposition party in elections. ${ }^{18}$

In Zimbabwe, centralisation takes three forms. First, there is the transfer of local authority functions to government-directed entities. Second, central government has usurped powers to influence who is appointed to manage cities. For instance, the abolition of executive mayors became a major constraint, as ceremonial mayors have no power to run city affairs. The central government has also centralised the recruitment of senior local authority executives, who essentially run cities, and this has had significant impact on the resultant service delivery. Third, there has been the introduction of new local government authorities in the form of provincial governors and district administrators in the metropolitan regions of Bulawayo and Harare.19 These government-appointed authorities dilute the power and authority of urban local authorities as they control land - a vital resource in urban development.

In essence, the centralisation of control and local government functions "politicised the local state'. ${ }^{20}$ The MDC controls urban areas, with ZANU(PF) controlling the local government ministry, leading to an ardently contested urban governance system. Intense contestation marks central-local government relations, leaving the electorate and residents confused about the direction of political change. ${ }^{21}$ Removing ZANU(PF) from managing urban areas was expected to be a way to usher in a new urban governance regime centred on effective and efficient service delivery. We argue, however, that for now, to some extent, the

\footnotetext{
${ }^{16}$ These are 5 from central government ministries, 6 from local authorities, 5 from urban social movements, 3 from political parties, 6 from non-governmental organisations and international development agencies, and 5 from consultancy, practising planners and research institutes.

17 W. Jonga, 'Prioritizing Political Banditry at the Expense of Good Governance: Rethinking Urban Governance in Zimbabwe', International Journal of Humanities and Social Sciences, 2, 24 (2012), pp. 117-35.

${ }^{18}$ Muchadenyika and Williams, 'Social Change'.

19 T.O. Ranger, 'City versus State in Zimbabwe: Colonial Antecedents of the Current Crisis', Journal of Eastern African Studies, 1, 2 (2007), 161-92.

${ }^{20}$ McGregor, 'Surveillance and the City', p. 788.

21 D. Muchadenyika, 'Contestation, Confusion and Change: Urban Governance and Service Delivery in Zimbabwe (2000-2012') (MPhil. dissertation, University of the Western Cape, 2014).
} 
new urban governance regime has shown unexpected results, mainly due to intergovernmental and inter-party contestations.

Between 2000 and 2012, the MDC control of urban centres increased at each election. For instance, in the 2008 elections, the MDC won 29 out of 30 urban councils with ZANU(PF) winning only one. ${ }^{22}$ Such a political reality turned urban administration into 'political battlegrounds rather than avenues of service delivery'.23

The commencement of the Inclusive Government in 2009 brought two institutional shifts that are relevant in understanding urban politics. First, the government ordered the return of water and sanitation functions to urban local authorities. Perhaps this was an attempt to transfer the water infrastructure burden to the opposition, which had won 29 of the 30 urban local authorities. The opposition was also in charge of other basic services, such as education and health, which had all but collapsed. At the same time, the MDC was responsible for the water ministry at the national level.

Second, the economic gains made during the Inclusive Government (2009-13) led to a sharp increase in car ownership in cities. Thus urban local authorities were receiving considerable revenue from vehicle licensing fees. In 2010, the national government, through the Zimbabwe National Road Administration (ZINARA), took over the vehicle licensing function from urban local authorities. It was under the Inclusive Government that toll gates were installed on all the country's major national roads as a strategy to fund road infrastructure maintenance. Between 2009 and 2013, urban political contestations centred mainly on access to and use of resources such as revenue and land.

After 2013, the ZANU(PF) regained exclusive control of the national government and made inroads in reclaiming some urban centres. However, city-state tensions continue primarily over the distribution of resources and sharing of functions. On 7 July 2015, Robert Mugabe's cabinet reshuffle changed the politics of urban control from primarily inter-party to intra-party politics. Ignatius Chombo's reign as local government minister came to an end after 15 years and he was replaced by Saviour Kasukuwere (also appointed ZANU[PF] National Political Commissar [NPC] in January 2015). Chombo's reign was characterised by the controversial dismissal of MDC mayors and councillors, OM/RO, the appointment of ZANU(PF)-aligned city commissions and a 'trail of ruin' and 'poor service delivery'.24

Being in charge of traditional leaders and 92 local authorities, controlling 1,958 ward councillors and being ZANU(PF)'s NPC made Kasukuwere powerful in both government and the party. Saviour Kasukuwere began a process of entrenching his political interests through a systematic purge of senior local authority officials appointed during the Chombo era. Affected were City of Harare and Mutare town clerks, and a number of directors within

\footnotetext{
${ }^{22}$ S. Chakaipa, 'Local Government Institutions and Elections', in J. de Visser, N. Steytler and N. Machinguta (eds), Local Government Reform in Zimbabwe: A Policy Dialogue (Cape Town, UWC Community Law Centre, 2010), p. 60.

${ }^{23}$ Muchadenyika and Williams, 'Social Change', p. 263.

${ }^{24}$ See 'Chombo Leaves Trail of Ruin, Poor Service Delivery', The Standard, Harare, 12 July 2015.
} 
the City of Harare were either forced to resign or retrenched. The argument presented to the public was cost-cutting and transparent city leadership. However, with time, such posts were refilled. This, we argue, is a political strategy to appoint people loyal to the new local government minister, using transparency as a facade.

The subsequent filling of town clerk vacancies created animosity between the local government minister and MDC councillors. In March 2016, for instance, the City of Harare mayor and councillors appointed businessman James Mushore as the new town clerk. However, the appointment was highly contested and failed to take effect, as the local government minister refused to authorise the appointment. From June 2015 to date, the City of Harare is run by an acting town clerk, as councillors and the local government minister are in disagreement on who to appoint. In Harare, the MDC tried to use the opportunity of the change of the local government minister to entrench its interests and influence the appointment of a new generation of senior city officials. But it faced resistance from the new local government minister.

Kasukuwere's reign as local government minister and NPC began to show clear signs of high political ambitions - through replacing city officials with loyal ones, commissioning investigations in city affairs (Harare, Mutare and Gweru) and purging those perceived to be from a different faction within ZANU(PF). To curtail Kasukuwere's power as local government minister, Robert Mugabe created a new ministry called Rural Development, Preservation and Promotion of Culture and Heritage, which took over 60 rural local authorities and traditional leadership from the local government ministry's mandate. This sequence of events suggests that, after the 2013 elections, the politics of urban control is largely determined by factions within ZANU(PF).

Zimbabwe's 2013 Constitution provides for devolution of powers and functions and recognises three tiers of government, namely national, provincial and local. As such, the Constitution provides for an Act of Parliament to provide and elaborate on the nature, structure and composition of devolution. The United Nations Development Programme (UNDP), through its Capacity Building and Service Delivery Programme, supported the local government law reform process. The process was highly contentious, with local authority officials clashing with local government ministry officials on how to implement devolution in practice. In August 2014, the Local Government All Stakeholders conference concluded that: '[d]elegates felt that centralisation will continue if the new laws did not sufficiently operationalise the 2013 Constitution'.25 Furthermore, local government stakeholders voiced concern on the contents of the new local government bills, stating that:

[t]he definition or the powers/competences of the President and Minister need to be elaborated in the new local government laws cognisant of the spirit and letter of devolution and particular attention given to ensuring citizen participation and the

\footnotetext{
${ }^{25}$ Ministry of Local Government, Public Works and National Housing, 'Towards New Local Government Legislation that is Consistent with the 2013 Constitution: Report on a Two-Day National Dialogue', dialogue convened by the Government of the Republic of Zimbabwe - MLGPWNH, Rainbow Towers, Harare, 27-28 August 2014, p. 4.
} 
constitutionally enshrined rights of the Provincial/Metropolitan and Local Authorities 'to govern on [their] own initiative'... . The significant and substantive reference to the Minister in the proposed bills raised anxiety as this was potentially sending the message that the current 'parent-child' relations would continue despite the 2013 constitution. ${ }^{26}$

Submissions from local government stakeholders were clearly ignored. Rather, the ZANU(PF)'s centralisation ideology is evident in the 2016 Local Government Laws Amendment Act. The Act was supposed to detail the scope and depth of devolution, providing functions and procedures of local authorities. ${ }^{27}$ But the Local Government Laws Amendment Act only deals with one thing - 'suspension and removal of councillors from office'. ${ }^{28}$ To reduce a whole constitutional chapter on provincial and local government to one thing - 'suspension and removal of councillors from office' - we argue, indicates that the ZANU(PF) government is not ideologically fit and ready to promote a devolved and developmental system of governance in the country. Instead, the government is preoccupied with control and making local governments subservient to the national government.

\section{Centralisation of Water and Sanitation}

After the establishment of major towns in the 19th century, urban local authorities in Rhodesia were responsible for providing water and sanitation services. This continued in the post-independence era, with the Public Health Act (Chapter 15.09) and Urban Councils Act (Chapter 29.15) providing the legal basis for local authorities to deliver and assure quality of water and sanitation services in urban centres. As part of water governance reforms, the Zimbabwe National Water Authority (ZINWA) was created in 1998 through the ZINWA Act. ZINWA's main functions are to advise government on the formulation of national policies and standards on water resources planning, management and development; water quality, pollution control and environmental protection; hydrology and hydrogeology; dam safety, borehole drilling and water pricing. ${ }^{29}$

In the 1990 s and 2000s, topical issues on urban water were clean water provision and the sourcing of water treatment chemicals. The crippling economic challenges and urbanisation affected the technical and financial capacity of local authorities to perform water and sanitation delivery functions. The national government continuously provided grants through quasi-fiscal operations to assist local authorities in water supply. After 2000, the supply of water treatment chemicals became a key source of tension. The national government and ZANU(PF) politicians had preferred suppliers who were, in most instances, linked to the ruling party. $3^{\circ}$ On the other hand, MDC mayors and councillors preferred either apolitical suppliers or those aligned to the MDC.

\footnotetext{
26 Ibid., p. 4.

${ }^{27}$ D. Muchadenyika, 'The Inevitable: Devolution in Zimbabwe - From Constitution-Making to the Future', in J. de Visser, N. Steytler, D. Powell and E. Durojaye (eds), Constitution-Building in Africa (Baden-Baden, Nomos Verlag and Community Law Centre, 2015), p. 126.

${ }^{28}$ Government of Zimbabwe, Local Government Laws Amendment Act, 2016 (Harare, Government Printer, 2016).

${ }^{29}$ Government of Zimbabwe, Zimbabwe National Water Authority Act, Chapter 20:05 (Harare, Government Printer, 1998).

${ }^{30}$ For details on how state contracts are awarded to ZANU(PF) companies, see M. Dawson and T. Kelsall, 'Anti-Developmental Patrimonialism in Zimbabwe', Journal of Contemporary African Studies, 30, 1 (2012), p. 52.
} 
Prior to the government of Zimbabwe's 9 May 2005 directive, urban local authorities were responsible for the delivery of water and sanitation services. However, the aforementioned directive compelled all urban local authorities to transfer water and sanitation functions to one government entity - ZINWA. Directives are an important tool to propagate and enforce government ideas and interests at the local level. These directives override council decisions and are commonly used in cementing government power in local government. ${ }^{31}$

Since independence, water has contributed the largest percentage of council revenue, making it a cash cow to local authorities. ${ }^{32}$ In 2006, for example, for the three cities of Bulawayo, Harare and Mutare, the average contribution of the water account to the total budget was 71.7 per cent. ${ }^{33}$ At the same time, water and sewerage infrastructure constituted more than 60 per cent of urban assets.34 These statistics buttress the argument in this article that centralisation is a strategy to control and access financial resources generated from urban residents. At the same time, the sphere of influence of urban local authorities was weakened, as 'water and sewer infrastructure were transferred at no cost'. 35

From the above, the takeover made ZINWA a huge cash resource, 'where ZANU(PF) would occasionally take the revenue to finance its activities'. ${ }^{6}$ Following this argument, the shift of water and sanitation functions from local authorities to ZINWA 'show government's desire to directly control water revenue rather than technical reasons'.37 Taking over the control of water from local authorities meant that central government and, by extension, the ruling party had control of the running of city affairs. This assertion affirms Swyngedouw's view that 'controlling of the flow of water implies controlling the city, as, without the uninterrupted flowing of water, the city's metabolism would come to a halt'. ${ }^{8}$ Erratic water supply characterised urban areas, though local authorities could do nothing, as they had lost control over the production and supply of water.

The local government ministry supported the takeover of water and sanitation functions, 'something that most local authorities were not expecting from the parent ministry'. 39 This, we argue, is also a result of the lack of clear and respected functional distinction between the local and national government. However, the City of Bulawayo refused to hand over water and sanitation functions to ZINWA. As such, city officials in Harare, Mutare and Masvingo

\footnotetext{
${ }^{31}$ Overall, local authorities view government directives as dangerous, paralysing councils. See 'Local Authorities Gang Up Against Chombo', NewsDay, Harare, 20 June 2011. For details on the role of directives in local authorities, see C.T. Chigwata, V.V. Muchapondwa and J. de Visser, 'Ministerial Directives to Local Government in Zimbabwe: Top-Down Governance in a Decentralized Constitution', Journal of African Law, 61, 1 (2017), pp. 41-56.

32 B. Coutinho, 'Sources of Local Government Funding', in Visser, Steytler and Machingauta (eds), Local Government Reform in Zimbabwe, pp. 71-86

${ }^{33}$ Bulawayo, 71per cent; Harare, 89 per cent and Mutare, 55 per cent. See Parliament of Zimbabwe (hereafter PoZ), 'Second Report of the Portfolio Committee on Local Government on the Takeover of Water and Sewerage Services', PoZ Senate Proceedings, Wednesday, 11 April 2007 (Harare, Parliament of Zimbabwe, 2007).

${ }^{34}$ See ibid.

${ }^{35}$ Muchadenyika and Williams, 'Social Change', p. 263.

${ }^{36}$ Interview with political analyst, Harare, 6 June 2013. All interviews for this article were conducted by Davison Muchadenyika.

${ }^{37}$ Interview with NGO director, Harare, 6 June 2013.

${ }^{38}$ E. Swyngedouw, Social Power and the Urbanisation of Water: Flows of Power (Oxford, Oxford University Press, 2004 ), p. 45.

${ }^{39}$ Interview with Urban Councils Association official, Harare, 26 June 2013.
} 
view the City of Bulawayo as not having political problems of the magnitude in other cities.40 It should be remembered that the 'intensity of the opposition of ZINWA's overtures in Bulawayo has its antecedents in the rejection of Bulawayo Waterworks Company by the municipality in the formative years of Bulawayo'.41 Bulawayo Waterworks Company was a private company responsible for water in Bulawayo between 1894 and 1924.

From the above, we argue that the rejection of ZINWA in Bulawayo is premised on three pillars. First, of all the cities, Bulawayo enjoys greater autonomy in terms of city management affairs. Thus we argue that the difference between Bulawayo and Harare is that the former is significantly divorced from central government while the latter is run as an extension of the national government. Second, since independence in 1980, politicians and professionals from Bulawayo have displayed unity in repelling central government moves deemed detrimental. Thus the combined resistance from politicians across the political divide, residents, civil society and city officials was instrumental in resisting ZINWA's takeover in Bulawayo.

Third, the droughts during the 1980 s and 1990 os in Bulawayo raised critical awareness among residents on the value of water in the city. Whoever wants to tamper with water there is deemed an 'enemy'. The conceptualisation of water in the city triggered collective resistance against ZINWA. But the situation is different in the other major cities, including Masvingo, Harare, and Mutare, with water issues becoming topical only during and after the 2008 cholera outbreak.

Our interviewees indicated that the takeover of water and sewerage functions showed a 'power battle'. ${ }^{2}$ The evidence for this is the transfer of assets from urban local authorities to ZINWA, circumventing legal compliance issues such as asset valuations. ZINWA was selling bulk water to the City of Harare from a City of Harare dam - an unusual institutional arrangement that brought tensions. Politicians of that time saw 'water as a game changer', 43 with whoever was controlling water seen as powerful. The state saw itself 'as mighty and powerful and that it can do anything'. 44 Thus the government of Zimbabwe 'continued to treat ZINWA as an extension of itself, financially propping it up, and defending it to the hilt even in the face of palpable operational deficiencies, to further its political objectives'. 45 The central government saw water as a national asset that could not be entrusted to the opposition party. Nevertheless, the Urban Councils Act was not changed, as it was only a policy directive from central government. In other words, according to Section 168 (powers of council in regard to sewerage and drainage) and Section 183 (powers of council in relation to water supply) of the Urban Councils Act, urban councils are still mandated to provide water and sanitation services in their areas of jurisdiction.

\footnotetext{
${ }^{40}$ Various interviews with city planners: Harare, Masvingo and Mutare.

${ }^{41}$ Musemwa, Water, History and Politics, p. xxvii.

${ }^{42}$ Interview with residents' association director, Harare, 9 July 2013.

${ }^{43}$ Interview with former city planner, Masvingo, 10 June 2013.

${ }^{44}$ Interview with senior planning consultant, Bulawayo, 17 June 2013.

${ }^{45}$ Musemwa, 'From “Sunshine City"', p. 187.
} 
At the takeover by ZINWA, local authorities were struggling to deliver water. In light of this, one can argue that central government tried to reduce the burden on local authorities. ZINWA was managing catchment areas, providing water to government institutions and rural local authorities prior to the May 2005 directive. Water is managed as a cycle, and therefore it can be argued that the takeover of water was a comprehensive water management attempt. Despite this, Manzungu and Mabhiza found that the election of the MDC to run the City of Harare subsequently saw water being a political issue with the local government ministry undermining opposition-led councils.46 A 2002 study in the City of Mutare concluded that politicians meddled in water issues in the city, as 'this will portray them as the provider of a life-giving resource that enhances health, security and prosperity'.47 In spite of this, our argument goes beyond merely identifying political motivations behind the ZINWA takeover. We also include ideological inclinations and the battle to control and access water revenue.

The historical antecedents of central government taking over council functions at zero cost were also witnessed in the delivery of energy services, long before party politics was an issue in local elections. In 1986, cities of Harare and Bulawayo power stations were taken over by the Zimbabwe Electricity Supply Authority (ZESA), a central government- controlled entity, at zero cost. Thus, besides political motives during centralisation since 2000, we argue that the ZANU(PF) government believes in centralisation as a political strategy and tool of organising the state. Such an ideological stance led to the national government taking over functions such as health, education and energy in the 1980s and 1990s. This is despite weak government capacity to deliver such functions. $4^{8}$ Thus, we argue here that the government's belief in centralisation is a vital element in explaining post-2000 politics of urban control. In this instance, conventional analyses of seeing centralisation as a political struggle between ZANU(PF) and MDC are therefore not sufficient.

\section{ZINWA and the Delivery of Water and Sanitation Services}

Centralisation of water and sanitation functions had severe impacts on the delivery of water and sanitation services in Zimbabwe's cities. Chief among these were the collapse of service delivery and revenue collection, severe human resources challenges and the deterioration of water assets. Central government failed to administer ZINWA, as evidenced by the collapse of water and sanitation services nationwide. The supply of water in Harare, for example, became more erratic following the ZINWA takeover: there was repeated bursting of major water pipelines. 49

In other words, ZINWA lacked technical and financial capacity to manage water and sanitation services. The government entity was inexperienced, under-capacitated and too

\footnotetext{
${ }^{46}$ E. Manzungu and C. Mabiza, 'Status of Water Governance in Urban Areas in Zimbabwe: Some Preliminary Observations from the City of Harare', Physics and Chemistry of the Earth, 29, 15-18 (2004), pp. 1167-72.

${ }^{47}$ B. Gumbo, and P. van der Zaag, 'Water Losses and the Political Constraints to Demand Management: The Case of the City of Mutare, Zimbabwe', Physics and Chemistry of the Earth, 27, 11-12 (2002), p. 812.

${ }^{48}$ D. Muchadenyika, 'Civil Society, Social Accountability and Service Delivery in Zimbabwe', Development Policy Review, 35, S2 (2017), pp. O178-O195.

${ }^{49}$ I. Chirisa and W. Jonga, 'Urban Local Governance in the Crucible: Empirical Overtones of Central Government Meddling in Local Urban Councils Affairs in Zimbabwe', Theoretical and Empirical Research in Urban Management, 4, 3 (2009), pp. 166-82.
} 
political, in that the delivery of safe, clean water to residents was secondary. $5^{\circ}$ The shift to ZINWA was at the expense of urban residents, who suffered water-borne diseases and water rationing. The United Nations Children's Fund (UNICEF) drilled hand-pump boreholes in most cities to mitigate the situation. In short, the takeover by ZINWA was a 'litmus test by the ZANU(PF) government to have a stake in service delivery to urban residents though it turned out to be a nightmare'. ${ }^{5}$

ZINWA personnel were "poorly remunerated compared to when under local authorities, affecting personnel morale and performance'. ${ }^{2}$ Even to this day, there is a personnel crisis still unresolved, as some urban local authorities refused to take back the politically appointed staff.53 In towns and cities where ZINWA still manages water, ZINWA sells bulk water to local authorities at exorbitant rates. However, such local authorities pass the cost to residents, portraying contestation in water management.54

Water billing services remained in the hands of urban local authorities, with ZINWA mandated with the production and supply of water. This arrangement seriously challenged institutional co-ordination. Local authorities had not willingly surrendered water and sanitation services, and 'therefore were sabotaging ZINWA'.55 The sabotage was demonstrated by poor and inconsistent water billing by local authorities, which resulted in a sharp decline in revenue handed over to ZINWA. ${ }^{6}$

We argue that the national government's centralisation of water and sanitation was largely retrogressive. ZINWA was characterised by the looting and mismanagement of water infrastructure. Such looting included the wanton removal of water pumps 'from urban local authorities (for instance Ruwa) and installing them on farms owned by top ZANU(PF) officials'.57 This illustrates that access to resources is a key driver of centralisation in Zimbabwe. In essence, assets were taken over by ZINWA, but liabilities were mainly returned to urban councils. In Mutare, for instance, the town clerk felt that ZINWA had vandalised infrastructure, as ZINWA inherited 85 per cent of the infrastructure in good working order but handed it back with only 45 per cent functional. 58

To substantiate government's rushed decision and the politicisation of such decision, we cite the Auditor and Comptroller General's 2007 report.59 The report shows the extent of ZINWA's incapacity in delivering its mandate even before taking over from urban local authorities. But the government ignored these findings and recommendations. The Auditor and Comptroller General revealed that:

\footnotetext{
${ }^{50}$ Various interviews: with city planner, government planner, NGO director, planning consultant.

${ }^{51}$ Interview with former Harare city planner, Harare, 15 July 2013.

${ }^{52}$ Interview with former local government permanent secretary, Harare, 14 June 2013.

${ }^{53}$ For example, Gwanda refused to take over ZINWA staff, though the latter retaliated by raising bulk water tariffs. However, the former has to pass on the cost burden to residents.

54 'Chinhoyi Mayor Blasts ZINWA Billing', NewsDay, 21 August 2012.

${ }^{55}$ Interview with residents' association director, Harare, 9 July 2013.

${ }^{56}$ Muchadenyika, 'Contestation, Confusion and Change'.

${ }^{57}$ Interview with political analyst, Harare, 6 June 2013.

58 'Mutare Water Going to Waste', NewsDay, 20 August 2012.

${ }^{59}$ Changed to Auditor-General under part 5, Section 309-314 of the 2013 Constitution of Zimbabwe.
} 
[m]y audit revealed that ZINWA was failing to provide undisrupted water supply and water of the right quality to its customers in small towns, growth points and institutional customers such as Prison Services, Zimbabwe Republic Police and the Defence Forces ... My visits to the water treatment stations in the catchment areas revealed that maintenance of plant and equipment was not being done according to standards set by management, and according to the manufacturer's specifications ... Based on the station inspections which I conducted in the catchment areas, I concluded that maintenance was not being taken as a priority by the authority. I observed that pumps and pipes were rusty and leaking and not all gate valves were working ... The tanks (reservoirs) were not cleaned at regular intervals. The walls of treatment tanks at most stations were almost falling apart due to cracks and leakages caused by lack of maintenance. ${ }^{60}$

In comparison to local authorities, ZINWA performed worse as the water crisis became more pronounced, until the government reversed its policy. ${ }^{61}$ The policy reversal is an admission of failure by government to control the supply of urban water through ZINWA. Water and sanitation challenges had become a serious security threat with the potential to destabilise ZANU(PF) rule. Government admitted the incapacity of ZINWA:

[t]he capacity of ZINWA to effectively manage water supply and sewer reticulation throughout the country's urban centres is severely overstretched. The centralisation of water management in ZINWA has been characterised by bureaucratic inefficiencies, leading to low staff morale ... Government is, therefore, decentralising the management of water to local authorities with effect from 1 February 2009. This entails that ZINWA reverts back to its status prior to the directive of 9 May 2005. Accordingly, ZINWA and local authorities should begin the processes for smooth hand over and take over transfers. ${ }^{62}$

However, local authorities were in the weakest position to deliver water and sanitation services after taking over from ZINWA. Despite this, the Parliament of Zimbabwe reported that 'since it [the City of Harare] took over the provision of water from ZINWA, water supply to residents had improved by 76.67 per cent from 300 mega litres to 530 mega litres per day and the number of people [with] access [to] potable water increased by 70 per cent from 2 million in June 2009 to 3.4 million in January 2010'.63 To date, urban local authorities such as Plumtree, Karoi, Gokwe and Mvurwi, among others, are still engaged in a contest with ZINWA over the management of water and sanitation. 64

\footnotetext{
${ }^{60}$ Auditor and Comptroller General, 2007, cited in PoZ, 'Second Report of the Portfolio Committee on Local Government'.

61 'ZINWA Fails to End Water Woes', The Herald, 28 September 2006; 'Water Crisis Worsens: Students Carry Water for Drinking, Toilet Use', Sunday Mail Metro, Harare, 1 October 2006; 'ZINWA Must Deliver: Gono', The Herald, 27 July 2007 ; 'ZINWA Creates New Pandemic: Dr P. Chimedza', Sunday Mail, Harare, 19 August 2007; 'Water Blues Haunt Budiriro ... as Residents Resort to Unprotected Wells', Sunday Mail, 26 September 2007; 'Water Woes to Continue - Experts', Zimbabwe Independent, Harare, 13 October 2007'.

${ }^{62}$ Ministry of Finance, 2009 National Budget (Harare, Ministry of Finance, 2009), p. 54.

${ }^{63}$ PoZ, 'Report on the Public Hearings on the State of Services Delivery by the Municipalities of Harare, Chitungwiza and Norton by the Local Government, Urban and Rural Development Portfolio Committee', p. 33.

${ }^{64} \mathrm{~K}$. Chatiza and N. Marongwe, '14 Small Towns WASH [water, sanitation and hygiene] Qualitative Baseline Survey: Report of Findings', (Harare, UNICEF, 2015).
} 


\section{Water, Sanitation and Urban Residents}

Here we explore the impacts of the centralisation of water and sanitation to urban residents. ZINWA did not properly manage the water resources and infrastructure. Water charges increased more than tenfold but without any noticeable changes in water supply and quality. ${ }_{5}$ Frequent bursting of water pipes was driven by a lack of maintenance skills, knowledge and experience on the part of the new authority. In many suburbs, such as Crowborough, Glen Norah and Glen View (Harare), water became severely rationed and used to be provided on two days per week. Residents were supplied with unclean, unsafe water because the "contracts with companies which used to supply the City of Harare with water chemicals were terminated with new found suppliers failing to meet the demand'. ${ }^{6}$ Residents were the worst affected, as a town planner pointed out: '[t]hey are the ones who went for days, months, and years without running water. They are the ones who experienced raw sewage gushing out of sewer pipes. They are the ones who had to look for alternative sources of clean water. ${ }^{67}$ Residents succumbed to diseases like cholera and typhoid. The cholera outbreak claimed 4,000 lives ${ }^{68}$ - the highest fatality rate in Africa for 15 years. ${ }^{69}$ However, Part 9 (sanitation and housing) of the Public Health Act compels local authorities to prevent or remedy danger to health arising from 'any well or other source of water supply or any cistern or other receptacle of water, whether public or private, the water which is used or likely to be used by man for drinking or domestic purposes'.70 Thus local authorities were hamstrung and could not fulfil the mandate of delivering safe, clean, reliable water. The situation in urban areas began to resemble that in rural areas, characterised by deep boreholes and shallow wells as the primary sources of water for most residents: a reversal of decades of urban infrastructural development. These wells were widely condemned as having contaminated water, which gave rise to water-borne diseases. ${ }^{71}$

The absence of a centralised water authority created by the handing over of water supply functions from ZINWA to local authorities created some problems of co-ordination in sharing water resources and infrastructure between local authorities. This is shown in the case of Rockview housing project, developed by Shelter Zimbabwe in Epworth:

[o]n 20 May 2008, Shelter Zimbabwe submitted an application to ZINWA for a water connection from the existing 350-mm ZINWA Ventersburg-Ruwa main that runs parallel to Harare-Marondera railway line. On 9 September 2008, ZINWA approved the water connection of Rockview Park to the Ruwa main. In 2009 ZINWA handed over water supply services to local authorities. City of Harare and Ruwa refused to recognise the connection of the project to the Ruwa main, arguing that ZINWA made an error: it should

\footnotetext{
${ }^{65}$ Musemwa, 'From “Sunshine City”, p. 190.

${ }^{66}$ Interview with government planner, Marondera, 5 July 2013.

${ }^{67}$ Interview with practising planner, Masvingo, 13 June 2013.

${ }^{68}$ International Crisis Group, Zimbabwe: Engaging the Inclusive Government, Africa Briefing No. 59 (Brussels, ICG , 2009).

${ }^{69}$ D. Acemoglu and J.A. Robinson, Why Nations Fail: The Origins of Power, Prosperity and Poverty (London, Profile Books, 2013), p. 369.

${ }^{70}$ Government of Zimbabwe, Public Health Act, Chapter 15: 09 (Harare, Government Printer, 1978).

${ }^{71}$ E. Zingoni, D. Love, C. Mugadza, W. Moyce and K. Musiwa, 'Effects of a Semi-Formal Urban Settlement on Groundwater Quality: Epworth (Zimbabwe): Case Study and Groundwater Quality Zoning', Physics and Chemistry of the Earth, 30, 11-16 (2005), pp. 68088; A. Nyemba, E. Manzungu, S. Masango and S. Musasiwa, 'The Impact of Water Scarcity on Environmental Health in Selected Residential Areas in Bulawayo City, Zimbabwe', Physics and Chemistry of the Earth, 35, 13-14 (2010), pp. 823-27.
} 
have consulted the two councils prior to granting the connection ... City of Harare, Epworth local board and Ruwa local board should have developed a common infrastructure that would service Zimre Park, Sunway City, Rockview Park and other upcoming housing projects in Epworth, Ruwa and Harare. To have the Shelter Zimbabwe bulk water line crossing the Sunway City bulk water line and all getting supplies from the same source is an act of gross lack of integrated planning of off-site infrastructure by local authorities concerned. $7^{2}$

Here we argue that there is essentially no attention given to integrated planning of water resource infrastructure: for instance, between developments in proximate areas but under different local authority jurisdiction. However, ZINWA was a central body that provided a platform for integrated infrastructure planning, development and sharing of water resources between local authorities.

When ZINWA took over water and sanitation functions, it employed local authorities to bill and collect water charges. Revenue collection systems went down 'as local authorities were not collecting the charges properly, as a way of sabotaging ZINWA'.73 When water and sanitation services were handed back to local authorities, local authorities revised the revenue collection system. As a result, bills increased and residents were unable to pay, though central government interfered through ordering local authorities to scrap all outstanding bills.74 However, such political interference affected the viability of local authorities, as it 'increased the number of people not willing to pay'.75 In summary, ZINWA's operational deficiencies and lack of financial and technical capacity ${ }^{6}$ meant that residents suffered most, owing to political struggles over the control of water in urban areas.

\section{Centralisation of Vehicle Licensing}

The centralisation of vehicle licensing reinforces our argument that revenue needs must be considered alongside political issues in analysing the motivation for the centralisation of services. This section examines the effects of the government's centralisation of vehicle licensing functions. The history of local authorities collecting vehicle licensing fees dates back to the mid 2oth century. For example, the City of Harare started collecting vehicle license fees in 1961. The Vehicle Registration and Licensing Act (VRLA) (13.14) recognises local authorities as Roads Authorities with the power to collect vehicle licensing revenue. Section 31 (1) of the VRLA gives powers to the minister responsible for transport to grant powers and permission to local authorities to charge license fees for vehicles ordinarily kept at night in their jurisdictions. 77 The beneficiaries of vehicle license fees are local authorities, acting on behalf of the Road Fund.

\footnotetext{
${ }^{72}$ Interview with Shelter Zimbabwe projects officer, Harare, 17 June 2013.

${ }^{73}$ Various interviews: with city manager, government town planner, former city planner.

74 'Chombo Scraps Water Bills', NewsDay, 23 July 2013.

${ }^{75}$ Interview with former local government permanent secretary, Harare, 14 June 2013.

${ }^{76}$ Musemwa, 'From "Sunshine City".

${ }^{77}$ GoZ, Vehicle Registration and Licensing Act, Chapter 13: 14 (Harare, Government Printer, 1994).
} 
Since its formation in 2001, ZINARA was 'responsible for reviewing annual work programs and budgets submitted by the road authorities and consolidating them into a single national road maintenance work programme'. ${ }^{8}$ However, the contest for urban control led to the centralisation of vehicle licensing, though it further strained centre-local state relations. $79 \mathrm{We}$ argue, again, that such centralisation was not primarily about undermining political opponents who had gained control over the urban councils, but is explained by central government's need to control financial resources generated from predominantly urban residents. Between 2009 and 2010, the country's passenger vehicle fleet increased from 500,000 to about 600,000, the largest yearly increase since 2000.80 Such figures suggest that vehicle licensing is a significant revenue source. By 2020, the African Development Bank projections indicate that a total of US $\$ 245$ million will be realised from vehicle licenses fees annually. ${ }^{81}$ The failure of the formal economy has seen the ZANU(PF) government devising new ways of raising revenue through taking over local authority functions.

The VRLA mandates local authorities to collect and administer vehicle license fees. Section 31 (2) of the VRLA provides that:

[t]he proceeds of fees charged, levied and collected in terms of subsection (1) shall after deduction by the local authority of any administrative fees fixed by the Road Administration in terms of section 54, be held by the local authority on behalf of the Road Fund and be used by the local authority in a manner approved by the Road Administration. 82

It is recognised that local authorities in Zimbabwe had been collecting motor vehicle license fees with some degree of success. ${ }^{83}$ In theory, the relationship between the Road Fund and local authorities is meant to bolster checks and balances - each entity should account to the other.

Local authorities (rural and urban) are designated as autonomous under the Roads Act (Chapter 13.18), with autonomy in the management of road infrastructure services in their areas of jurisdiction. ${ }^{84}$ In 2010, however, local authorities were 'surprised to learn that the license fees collection functions had been removed and placed into the hands of the Zimbabwe Posts (ZIMPOST) with no formal communication from the ZINARA or the Ministry of Transport, Communication and Infrastructure Development'. ${ }^{85}$ Rather, vehicle licensing functions were taken away from local authorities to the ZINARA through a government directive. ${ }^{86}$ This is despite the fact that, according to section 52 of the VRLA,

\footnotetext{
${ }^{78}$ African Development Bank (AfDB), Infrastructure and Growth in Zimbabwe: An Action Plan for Sustained Strong Economic Growth in Zimbabwe (Tunis, AfDB, 2011), p. 206.

${ }^{79}$ For example, see 'Council Engages Government over ZINARA', City of Harare Press Statement, 20 September 2016.

${ }^{80}$ The passenger fleet is expected to increase to nearly 1 million by 2020. See AfDB, Infrastructure and Growth in Zimbabwe, p. 209.

${ }^{81}$ See ibid., p. 231.

${ }^{82} \mathrm{GoZ}$, Vehicle Registration and Licensing Act (emphasis added).

${ }^{83}$ Zimbabwe Local Government Association (ZILGA), 'Position Paper on Vehicle Licensing' (unpublished paper, Harare, 2012).

${ }^{84}$ AfDB, Infrastructure and Growth in Zimbabwe.

${ }^{85}$ ZILGA, 'Position Paper on Vehicle Licensing'.

86 Ibid.
} 
such actions require a Statutory Instrument. The Statutory Instrument to effect this change was gazetted only in $2013 \cdot{ }^{87}$

The purpose of vehicle licensing fees is to maintain road infrastructure. But some local authorities were using roads funds for administrative purposes. ${ }^{88}$ It can be argued that the centralisation of vehicle licensing through the ZINARA was an attempt to reduce the abuse of vehicle license funds by local authorities. Nevertheless, the association of local authorities argues that 'the transport ministry used an excuse of one rural local authority (Wedza) which misused vehicle licensing funds as the reason for withdrawing the function from local authorities' ${ }^{89}$ In that regard, section 32 (1) of the VRLA provides for circumstances where the minister responsible for transport may collect fees on behalf of the local authority:

[i]f in the opinion of the Minister, a local authority fails or is unable to collect all or any part of the fees payable to it in terms of this Act, the Minister may undertake the collection of such fees on behalf of the local authority and recover from such local authority any costs incurred by him in that connection. $9^{\circ}$

However, this is not what obtains in Zimbabwe. Therefore we contend that the Ministry of Transport should have conducted an assessment of the 92 local authorities to determine the state of roads funds abuse. Such an assessment could have assisted in selecting local authorities where the ministry can collect vehicle license fees on behalf of such local authorities. The lack of such a credible assessment gives room to argue that the government has an ulterior motive in taking over vehicle licensing functions.

There are two reasons that can justify government takeover of vehicle licensing functions. First, poor accounting systems: 'there were incidences of fake vehicle licenses depriving local authorities of revenue'. ${ }^{1}$ Second, the enforcement of vehicle licensing by local authorities through the municipal police was weak, resulting in low revenue collected. Based on these two reasons, one can argue that poor management by local authorities was responsible for the decision taken by the government. However, local authorities are of the view that each local authority 'should have been advised of its shortcomings before such drastic actions were taken and that the current arrangement of distributing funds through the ZINARA is unsustainable'.92

In the view of our interviewees, the idea of centralisation by the government was 'premised on power, control and opportunities for rents'.93 ZINARA became an instrument in the hands of the government to centralise vehicle license fee collection, as the government lacked

\footnotetext{
${ }^{87}$ GoZ, Statutory Instrument 141 of 2013: Vehicle Registration and Licensing (Amendment) Regulations, 2013 (No. 15), (Harare, Government Printer, 2013).

${ }^{88}$ For instance, paying for salaries.

${ }^{89}$ Interview with Urban Councils Association official, Harare, 26 June 2013.

${ }^{90}$ GoZ, Vehicle Registration and Licensing Act (emphasis added).

${ }^{91}$ Interview with city official, Harare, 10 June 2013.

${ }^{92}$ ZILGA, 'Position Paper on Vehicle Licensing', p. 2.

${ }^{93}$ Interview with planning consultant, Masvingo, 17 June 2013. For a detailed analysis of economic rents and ZANU(PF) rule, see Dawson and Kelsall, 'Anti-Developmental Patrimonialism in Zimbabwe'.
} 
the financial capacity to maintain rural roads. Thus, taking the function from local authorities is a strategy to spread road funds across the country. 94 In essence, the transport ministry, through ZINARA, skews allocation of vehicle licensing funds to ZANU(PF) strongholds. 95 This is mainly because, at present, there is no defined and credible formula for sharing funds among the 92 local authorities. As such, ZINARA plays a redistribution role to all local authorities irrespective of the number of cars, road coverage and state of the road network. Consequently, the City of Harare 'publicly expresses its displeasure with the revenue allocation processes'. ${ }^{9}$ Here we argue that centralisation of vehicle licensing through ZINARA is a strategy to harness urban-generated resources and distribute them to rural areas loyal to the ruling party. Thus the divide in terms of rural-urban politics is also manifested in the centralisation of vehicle licensing.

Allocation by ZINARA does not take into account the geographical concentration of license payers and vehicles. Thus the vehicle licensing takeover disconnected licensing from the city's capacity to maintain its road network. But decentralisation of roles and responsibilities remained (road maintenance remains the function of local authorities), with revenue centralised. Therefore central government interference in road management through ZINARA affects the ability of local authorities to repair and maintain roads through vehicle licensing.

Urban local authorities are of the view that 'where they are making some revenue, central government takes over the function'. 97 Six council officials argued that central government had no reliable revenue streams and therefore vehicle licensing became an easy option in response to government 'bankruptcy'. ${ }^{8}$ Thus ZANU(PF) tried to take political life out of urban areas through 'centralising possible revenue streams for MDC-run councils'. 99 One can argue that ZINARA is an attempt to under-resource urban councils: the councils fail to get enough revenue to service urban areas, and their failure is often ascribed to MDC-run councils. Urban areas are battlefields by virtue of being run by the MDC: 'every aspect of it be it water, road maintenance, and housing - are contested and politicised'. ${ }^{100}$

Central government's continued centralisation of functions affects the service delivery capacities of urban local authorities. In light of this, local authorities are reduced to carrying out administrative work, as central government persistently grabs their substantive functions. ${ }^{101}$ With access to vehicle licensing revenue, 'the party [MDC] would make significant developments in infrastructure development, and ZANU(PF) would be seen as a failure'. ${ }^{102}$ In this regard, the City of Bulawayo mayor argued that, if vehicle licensing was to

\footnotetext{
94 The premier institution mandated with maintenance of rural roads, the District Development Fund, has since become financially bankrupt. Hence it can no longer perform its functions.

95 'Government Pledges to Pay \$41 million Debt', NewsDay, 27 June 2012.

${ }^{96}$ Interview with city manager, Harare, 24 July 2013.

${ }^{97}$ Ibid.

98 Various interviews with local authority officials.

${ }^{99}$ Interview with former MDC councillor, Harare, 3 June 2013.

${ }^{100}$ Interview with government planner, Marondera, 5 July 2013.

101 'Disband ZINARA - Mayors', Daily News, 27 November 2012.

${ }^{102}$ Interview with MDC policy strategist, Harare, 19 June 2013.
} 
be returned to local authorities, they were going to transform the status of roads in urban areas. ${ }^{103}$

Apart from politics, two questions arise: previously, when urban local authorities had vehicle licensing responsibility, what did they achieve? And how are the ZINARA funds accounted for? While local authorities were carrying out routine maintenance, evidence also suggests the use of road funds for other administrative expenses. Nevertheless, it is clear that ZINARA is 'a mechanism that ensures funds from vehicle licensing are used for road maintenance and not salaries of local authorities' personnel'.104 Despite this, other rural local authorities are still abusing funds allocated to them for road maintenance by ZINARA. ${ }^{105}$

Though it collects revenue from motorists, ZINARA has no accountability framework to them. There is no pressure for it 'since it does not have any constituency except being part of a central government ministry'. ${ }^{106}$ The efficiency and corporate accountability of ZINARA is weak. Moreover, ZINARA is not sufficiently separate from central government, causing the entity to be seen as a 'revenue generating vehicle for central government'. ${ }^{107}$ Further, ZINARA funds are not properly accounted for, as it is alleged that 'US\$20 million is reported to have vanished'. ${ }^{108}$ The 2011 Auditor General's report corroborates the finding of poor accounting systems in the administration of ZINARA funds.

In my 2010 report, I mentioned that the Ministry (of transport and infrastructure development) failed to account for funds amounting to US\$2,751,872. The same problem persisted in 2011. The Zimbabwe National Roads Administration (ZINARA) financial statements, showed a disbursement of US $\$ 16,199,546$ to the Department of Roads Fund for maintenance of roads throughout the country. However, according to the Fund's financial statements, only US $\$ 10,650,579$ was received from ZINARA. The two figures could not be reconciled and I was not able to determine which figure was accurate. ${ }^{109}$

ZIMPOST, the national postal operator and a government entity, was the first to be designated an agent to collect vehicle license fees on behalf of ZINARA. ${ }^{110}$ At the time, government realised that it faced the "collapse of ZIMPOST, despite having huge infrastructure around the country'.111 It was essential to rescue ZIMPOST and therefore government took over the function (of collecting vehicle licenses) from local authorities. From the above, we argue that centralisation of local authority functions allowed the rescue of government agencies, in this case preventing the looming collapse of ZIMPOST.

\footnotetext{
103 'Disband ZINARA - Mayors', Daily News, 27 November 2012.

${ }^{104}$ Interview with residents' association director, Harare, 9 July 2013.

105 'Council Bosses Blow ZINARA Funds, Court Told', The Herald, 3 January 2013.

${ }^{106}$ Interview with Urban Councils Association official, Harare, 26 June 2013.

107 Ibid.

${ }^{108}$ Interview with NGO worker, Masvingo, 17 July 2013.

${ }^{109}$ Auditor General, Narrative Report 2012: Finance Accounts (Harare, Office of the Auditor General, 2012), p. 61.

${ }^{110} \mathrm{GoZ}$, 'Statutory Instrument 141 of 2013'.

${ }^{111}$ Interview with projects and administration officer, Harare, 19 July 2013.
} 


\section{ZINARA and Road Infrastructure Maintenance}

The Zimbabwe National Road Administration primarily maintains national rather than urban roads, though not comprehensively. In fact, the entity tends to patch up roads rather than overseeing a complete overhaul of the road infrastructure network. A senior planning consultant argued that ZINARA is looking at 'one's face and not the rest of the body'. ${ }^{112}$ Access roads in all cities are derelict and unattended to. However, motorists often 'accuse councils and not ZINARA for not maintaining city roads'. ${ }^{113}$ This has a tendency to strain relations between local authorities and residents.

The allocation of ZINARA funds from both toll gates and vehicle licensing is questionable, as some 'local authorities in ZANU(PF) strongholds have benefited more than big cities'.114 As such, revenue collected in major cities such as Harare and Bulawayo benefits people in other areas who might not have contributed. However, it appears to be no coincidence that ZINARA is an institution used to raise revenue from opposition strongholds and distribute to constituencies loyal to the ZANU(PF). Rather, it is a strategy in an environment where the key rural development institution responsible for maintaining rural roads - the District Development Fund - has all but collapsed.

From January to June 2016, ZINARA collected US\$74.6 million, with US\$69.4million disbursed.15 Disbursements to road authorities (local authorities) amounted to a paltry US $\$ 14.8$ million (19.8 per cent). However, the expenses incurred by ZINARA amounted to 35 per cent. ${ }^{116}$ This demonstrates that ZINARA is a costly structure that is consuming huge resources, which could be used for road maintenance. Of the US\$26 million collected from vehicle license fees between January and June 2016, only about 38.8 per cent had been disbursed to local authorities. ${ }^{117}$ The difference between collections and disbursements indicates the operational inefficiencies of ZINARA. Disbursements to the City of Harare (see Table 1) show how ZINARA is suffocating road maintenance in cities.

The government's budget allocation for road maintenance in local authorities is disbursed through ZINARA. For the 32 urban local authorities, of the budgeted US\$10 million, ZINARA disbursed about 23 per cent between January and June 2016.118 In 2015, urban local authorities received 57 per cent of the budgeted US $\$ 10$ million. ${ }^{119}$ Considering that urban local authorities are responsible for 8,190 kilometres of the road network, the Government of Zimbabwe is choking road maintenance by urban local authorities.

\footnotetext{
112 Interview with senior planning consultant, Bulawayo, 12 June 2013.

${ }^{113}$ Interview with Urban Councils Association official, Harare, 26 June 2013.

${ }^{114}$ Interview with residents' association director, Harare, 9 July 2013.

115 Ministry of Finance and Economic Development, The 2016 Mid-Year Fiscal Policy Review Statement: Improving Investor Confidence to Enhance Productivity (Harare, Ministry of Finance and Economic Development, 2016).

${ }^{116}$ Disaggregated as: revenue generation cost - US\$12 million; administration - US\$6.6 million; staff and management costs - US\$5.6 million.

${ }^{117}$ Ministry of Finance and Economic Development, 'The 2016 Mid-Year Fiscal Policy Review Statement'.

118 Ibid.

119 Figures as at 13 November 2015. See Ministry of Finance and Economic Development, The 2016 National Budget Statement: Building a Conducive Environment that attracts Foreign Direct Investment (Harare, Ministry of Finance and Economic Development, 2015).
} 
Despite this, ZINARA disburses funds to road authorities without making reference to budget allocations. The results of such arbitrary allocations has seen other road authorities 'receiving amounts 1,503 per cent over and above their allocation while others receive nothing. ${ }^{120}$ Table 2 shows significant variations between allocations and disbursements by ZINARA.

The association of local authorities told the local government ministry that the impact [of vehicle licensing takeover] will be highly negative in that roads will not be maintained and more legal suits will arise and council will lose significant amounts of funds compensating the complainants'. ${ }^{21}$ In addition, the Zimbabwe Local Government Association (ZILGA) noted that the public outcry about poor roads showed that residents were losing confidence in their local authorities. ${ }^{122}$ The relationship between central government and local authorities has been problematic in the 21st century. Primarily, this is explained by differences in visions and positions over the autonomy of local authorities. Central government often intervenes and distorts the operations of local authorities through usurping some powers and functions despite contestation by the latter.

Table 1. ZINARA disbursements to the City of Harare (2009-13) (US\$million)

\begin{tabular}{lccc}
\hline Year & City requirement & Actual disbursement & Equipment \\
\hline 2009 & 7 & 0.654 & - \\
2010 & 10 & 4.042 & - \\
2011 & - & - & - \\
2012 & 11.8 & 2 & Jet patcher \\
2013 & 23 & 0.550 & Jet patcher \\
\hline
\end{tabular}

Source: 'Harare Gets Crumbs from ZINARA', The Herald, Harare,16 October 2014.

Motorists in major cities like Harare and Bulawayo cumulatively pay more license fees, but, when vehicle licensing funds are allocated, equity issues are considered rather than traffic volume. The fund allocation criteria are questionable and politically motivated; the largest contributing cities are suffocated. Therefore it can be argued that ZINARA is an irrational model for urban road infrastructure maintenance.

\section{State of Road Infrastructure in Cities}

Zimbabwe has 8,190 kilometres of urban roads managed by urban local authorities. ${ }^{123}$ Rapid urbanisation and high urban poverty are straining municipal revenue streams, making expansion and maintenance of urban infrastructure difficult. ${ }^{124}$ This situation is exacerbated by road construction standards that have been severely compromised. This

120 Auditor General, 'Report of the Auditor General for the financial year ended December 31, 2014: Narrative Report on State Enterprises and Parastatals' (Harare, Office of the Auditor-General of Zimbabwe, 2015), p. 43.

121 ZILGA, 'Zimbabwe Local Government Association (ZILGA) Report on the Consultative Meeting between ZILGA-Urban and the Permanent Secretary: Mr K.T. Mupingo 5 March 2012 at 14.00 Hrs, 9th Floor Boardroom: Makombe Building' (unpublished paper, Harare, 2012), p. 4.

122 ZILGA, 'Position Paper on Vehicle Licensing'.

123 The condition of this road network is judged to be 35 per cent 'good', 25 per cent 'poor' and 40 per cent 'fair'. See AfDB, Infrastructure and Growth in Zimbabwe.

${ }^{124}$ K. Chatiza, M. Dhliwayo and D. Muchadenyika, Urban Infrastructure and Climate Change in Zimbabwe (Harare, Dialogue on Shelter and Zimbabwe Environment Regional Organisation, 2011). 
can be attributed to either absence of quality control or corruption in council construction works. Substandard construction products and temporary maintenance provided by most local authorities also explain the derelict road infrastructure. ${ }^{125}$ On the other hand, private property developers have been cheating homeowners by using substandard construction materials. ${ }^{126}$

Most local authorities are weak, characterised by corrupt tendering and procurement procedures. Tendering is opaque, 'with no plans and time for councillors to devote to this process, as councillors are preoccupied with taking decisions'.127 Lack of transparency in tendering and procurement compromise key council decisions and the resultant service offered. Corruption affects road infrastructure tenders. In most tenders, 'as long as councillors were involved, there is evidence of corruption'. ${ }^{128}$

The Auditor General's 2012 Report on local authorities pointed to corruption and funds mismanagement in local authorities in general and in particular procurement of goods and services. The report notes that:

Mutare City Council awarded a tender to Westgate Investments of US\$662,466 in respect of the supply of water pipes and fittings. This obligation was not honoured although Council made 50 per cent payment.... The Buhera Rural District Council management incurred unauthorised excess expenditure amounting to US\$130,752. Full Council Meeting Number 16 passed resolution $\mathrm{C} 244$ (b) which authorised the construction of a sewer line and ponds in by a private construction company at a cost of US\$298,568. By year end, by a private construction company at a cost of US\$298,568. By year end,

Council management had spent US $\$ 429,320$, which was 44 per cent way [sic] above the authorised limit of US\$298,568. Chipinge Rural District Council acquired three (3) vehicles from South Africa. There was no evidence to suggest that these acquisitions were done following proper procurement procedures. ${ }^{129}$

Although local authorities invite tenders, the selection criteria are not public knowledge. Tendering is thus a contested issue, because most companies that 'were awarded the tenders ... belong to council officials or politicians'. ${ }^{130}$ During field research, the authors were denied a roster of all tenders awarded over the past decade in major cities. Tendering was also influenced by the local government ministry, with tenders awarded to ZANU(PF) sympathisers. For instance, Umguza, Ruwa, and Harare councils

\footnotetext{
${ }^{125}$ Various interviews: with city manager, city planner, government planner, planning school lecturer.

${ }^{126}$ Muchadenyika, 'Contestation, Confusion and Change'.

${ }^{127}$ Interview with former MDC councillor, Harare, 3 June 2013.

${ }^{128}$ Interview with NGO director, Harare, 6 June 2013.

${ }^{129}$ Auditor-General, Report of the Auditor-General for the Financial Year Ended December 31, 2012: Local Authorities Volume 3 of 3 (Harare, Office of the Auditor General, 2014), p. viii.

${ }^{130}$ Interview with practising planner, Masvingo, 13 June 2013.
} 
were 'forced to pay in advance by the local government ministry for tender services not yet provided'. ${ }^{131}$

Of all the major cities in Zimbabwe, there is no evidence of infrastructure rehabilitation and development plans in excess of a 10-year planning period. This means that proactive development planning is largely, if not completely, missing in Zimbabwe. More specifically, it shows that infrastructure development and rehabilitation is not a top priority for local authorities. In addition, issues of poor planning, wrong priorities and bloated staff affect the capacity of urban local authorities to maintain infrastructure. ${ }^{132}$ Challenges to maintenance can also be attributed to central government, which no longer provides public sector investment programme grants that can support road maintenance. The formula for sharing vehicle licensing fees among local authorities by ZINARA seems dysfunctional and opaque. It would seem that the operation of ZINARA resembles 'ratepayers subsidising the state rather than the reverse'. ${ }^{133}$

Before 2000, road infrastructure was built before houses. After 2000, however, people were allowed to build houses without the infrastructure.134 The situation is haphazard, as local authorities lack the political will and technical and financial capacity to construct road infrastructure before houses. As such, the infrastructure is dilapidated, 'due to a combination of the politicisation of road infrastructure construction and maintenance, and economic instability'. ${ }^{135}$

The net effect of ZINARA on road infrastructure maintenance is a 'serious and negative one, the same effect with ZINWA (on water and sanitation) and ZESA (on electricity)'.136 Centralisation of various services, which occurred gradually in the post-independence era, destroyed service delivery institutional arrangements. Mutare, Harare, and Gweru generated and supplied their own electricity until January 1986, when ZESA was created out of an amalgamation of the mentioned three local authorities' electricity departments and two other companies. ${ }^{137}$ However, the subsequent energy crisis born of such centralisation continues unabated. ZINARA (roads), ZINWA (water and sanitation), ZESA (electricity) and Zimbabwe United Passenger Company (for rural and urban transport) allow central government - and, by extension, ZANU(PF) - to direct service delivery operations through parastatals. ${ }^{138}$ However, many of these parastatals are fraught with corporate governance malpractices. ${ }^{139}$

\footnotetext{
${ }^{131}$ Interview with political analyst, Harare, 6 June 2013.

${ }^{132}$ Interview with NGO director, Harare, 6 June 2013.

${ }^{133}$ Interview with city planner, Harare, 19 July 2013.

${ }^{134}$ As part of a parallel development policy adopted by the government of Zimbabwe and local authorities. While this policy has led to the reduction of cost in the process of building low-income housing by the urban poor, the policy has also led to non-development of road infrastructure in many new settlements.

${ }^{135}$ Interview with former local government permanent secretary, 14 June 2013.

${ }^{136}$ Interview with senior planning consultant, Bulawayo, 12 June 2013.

137 The other two companies are the Electricity Supply Commission and Central African Power Corporation.

${ }^{138}$ For a discussion on the role of parastatals in Zimbabwean political economy, see, G. Moyo, 'The Curse of Military Commercialism in State Enterprises and Parastatals in Zimbabwe', Journal of Southern African Studies, 42, 2 (2016), pp. 351-64.

${ }^{139}$ For example, the PoZ found out that ZUPCO has 'irregularities which ranged from non-payment of workers, unfair labour practices and violation of ZUPCO Articles of Association resulting in conflict of interest and failure to account for company assets'. See PoZ, 'Second Report of the Portfolio Committee on Local Government Rural and Urban Development on the Zimbabwe United Passenger Company (ZUPCO), Presented on 12th June 2012' (Harare, PoZ, June 2012), p. 2.
} 
Table 2. Variations between ZINARA allocations and disbursements to road authorities (2012-13)

\begin{tabular}{lccrr}
\hline Recipient & Year & Amount allocated (US\$) & Amount disbursed (US\$) & Variation (\%) \\
\hline Department of Roads & 2012 & $3,309,234$ & $14,389,365$ & 335 \\
Department of Roads & 2013 & 985,163 & $15,789,782$ & 1,503 \\
Kariba Urban Council & 2012 & 149,786 & 0 & -100 \\
Kariba Urban Council & 2013 & 93,616 & 0 & -100 \\
Rusape Town Council & 2012 & 123,746 & 891,810 & 621 \\
Rusape Town Council & 2013 & 93,012 & 668,343 & 619 \\
\hline
\end{tabular}

Source: Auditor-General, 'Report of the Auditor-General for the Financial Year Ended December 31, 2014: Narrative Report on

State Enterprises and Parastatals' (Harare, Office of the Auditor-General of Zimbabwe, 2015), pp. 43-4.

Centralisation in Zimbabwe goes back to the model of the one-party state, where government tries to do everything for the people yet in practice delivers virtually nothing. ${ }^{140}$ The government of Zimbabwe has a long history of 'taking over functions from local authorities with access to funds as the main reason'. ${ }^{141}$ Such levels of centralisation, we argue, indicate ZANU(PF)'s ideological underpinnings: the government believes in centralisation as a way to organise the state.

\section{Conclusion}

Both before and after 2000, the Government of Zimbabwe has been determined to strip local authorities of key functions. In this regard, existing scholarship attributes post-2000 centralisation to urban political struggles between the MDC and ZANU(PF). ${ }^{142}$ Drawing on the centralisation of water and sanitation and vehicle licensing, this article has argued that there are other compelling reasons that explain post-2000 centralisation. First, we argued that the pre- and post-2000 antecedents of centralisation indicate the ZANU(PF)'s firm belief in centralisation as a strategy for organising the state. Between 1980 and 2000, local authority functions such as health, education and electricity were taken over by government entities. Thus understanding post-2000 centralisation requires understanding relations between central and local government before 2000. In other words, the post-2000 centralisation is a manifestation of the ZANU(PF) government's fetish for it.

Second, the collapse of the economy in the post-200o era affected government revenue. As a result, it became imperative to manage directly urban cash-cow services, such as water and vehicle licensing. Such arrangements allow government occasionally to take such revenues and fund its programmes. At the same time, withdrawing functions that provide vital revenue to cities essentially weakens the administration of such cities.

Third, the ZANU(PF) government uses centralisation to maintain a firm grip on power. In spite of it being clear that the ZANU(PF) lost the electoral contest in urban centres to the opposition, the struggle shifted to a 'functions battle'. While a political party can win

\footnotetext{
${ }^{140}$ UNDP, Comprehensive Economic Recovery in Zimbabwe: A Discussion Document (Harare, UNDP Zimbabwe, 2008).

${ }^{141}$ Interview with former city planner, Harare, 10 June 2013.

${ }^{142}$ For instance, Musemwa, 'From "Sunshine City"'; Musemwa, Water, History and Politics; Musemwa, 'Disciplining a "Dissident" City'.
} 
elections to run cities, it is the ability to perform functions that demonstrates power. Thus centralising functions became a show of power and made the ZANU(PF) relevant in urban life, though it had lost elections.

Fourth, the divide between rural and urban areas in terms of political allegiances also explains centralisation of, in particular, vehicle licensing functions. The socio-economic and political challenges facing the country grounded key rural development institutions such as the District Development Fund (DDF). The DDF is mandated with, among other things, road maintenance in rural areas. After 2000, however, the DDF's financial and technical capacity was whittled away. In a balancing act, government took over vehicle licensing functions to distribute urban generated resources to rural areas.

The evidence presented in this article indicates that centralisation has adversely affected the delivery of services in Zimbabwe. The country's problems of service delivery - energy, water and sanitation, health, education, road infrastructure - are, in part, a result of the centralisation carried out by the government. In this regard, problems of service delivery within cities are largely a creation of the central government. In the post-independence era, evidence suggests that central government has opted to centralise local authority functions in return for political control, resources and maintaining power.

\section{DAVISON MUCHADENYIKA}

Institute for Social Development, University of the Western Cape, Private Bag X17, Bellville 7535, Cape Town, South Africa. Email: muchadenyikad@gmail.com JOHN J. WILLIAMS

School of Government, University of the Western Cape, Private Bag X17, Bellville 7535, Cape Town, South Africa. Email: jjwilliams@uwc.ac.za 